\title{
PENGARUH AROMATHERAPI EKSTRAK KULIT JERUK TERHADAP PENURUNAN TINGKAT KECEMASAN PADA PASIEN LUKA KAKI DIABETIK
}

\author{
Sulastri Sinaga, Rishka Widiya Utami*, Feny Florida Lumban Tobing, Rechelia Febra Ditha Br \\ Sembiring, Mirna Gea, Kristina L. Silalahi \\ Fakultas Keperawatan dan Kebidanan, Universitas Prima Indonesia, Jl. Danau Singkarak, Gg. Madrasah, \\ Sei Agul, Kec. Medan Barat, Kota Medan Sumatera Utara 20117, Indonesia \\ *rishkawidiyautami@gmail.com ( +6282277699496 )
}

\begin{abstract}
ABSTRAK
Tujuan penelitian ini untuk mengetahui tingkat kecemasan sebelum dilakukan pemberian aromatherapi ekstrak kulit jeruk pada pasien luka diabetic dan dilakukan sesudah pemberian aromatherapi ekstrak kulit jeruk pada pasien luka diabetic. Dalam Penelitian ini mengggunakan metode pre eksprementalone group pre-test dan post-test design. Teknik pengumpulan sampel yang digunakan dalam penelitian ini secara purposive sampling 15 responden, responden yang mengalami luka kaki diabetic dan mengalami kecemasan,pengambilan data penelitian ini accidental sampling. Kesimpulan dalam penelitian ini dengan uji quasy experimental design menunjukkan pengaruh Aromatherapi ekstrak kulit jeruk Pvalue=0.001<@=0.05). Kesimpulan tingkat kecemasan setelah pemberian Aromatherapi ekstrak kulit jeruk reponden berada pada tingkat kecemasan ringan.
\end{abstract}

Kata kunci: aromatherapi; diabetes; kulit jeruk

\section{THE EFFECT OF AROMATHERAPY FROM ORANGE PEEL EXTRACT ON DECREASING ANXIETYLEVEL IN DIABETIC FOOD WOUNDS PATIENT}

\section{ABSTRACT}

Objectives of this study were to determine the level of anxiety before giving aromatherapy orange peel extract to diabetic wound patients and after giving aromatherapy orange peel extract to diabetic wound patients. In this study, the pre-experimentalone group pre-test and post-test design methods were used. The sample collection technique used in this study was purposive sampling 15 respondents, respondents who experienced diabetic foot wounds and experienced anxiety, the data collection of this study was accidental sampling. The conclusion in this study with a quasy experimental design test showed the effect of aromatherapy orange peel extract (Pvalue $=0.001<@=0.05)$. Conclusion the level of anxiety after giving Aromatherapy orange peel extract respondent is at a mild level of anxiety.

Keywords: Aromatherapy; diabetes; orange skin

\section{PENDAHULUAN}

Diabetes adalah penyakit kronis yang di tandai dengan ciri-ciri berupa tingginya kadar gula (glukosa)darah.. Penyakit ini disebabkan teralu banyak makan dan minuman yang manis yang mengandung banyak gula.Kadar glukosa darah yang tinggi secara konsisten bisa menyebabkan penyakit serius yang mempengaruhi jantung, pembuluh darah, mata, ginjal, dan saraf. Penderita diabetes berisiko lebih tinggi mengalami masalah kesehatan (Qurniawati, 2020). 
Menurut Organisasi International Diabet Faderation( IDF) memperkirakan sedikitnya ada 483 juta orang pada umur 20- 79 tahun di dunia mengidap diabet pada tahun 2019 ataupun setara dengan angka prevalensi sebesar 9, 3\% dari total penduduk pada umur yang sama. IDF memperkirakan prevalensi diabet di tahun 2019 yakni 9\% wanita setelah itu 9,65\% pada pria. Prevalensi diabet diperkirakan bertambah bersamaan akumulasi usia penduduk jadi $19,9 \%$ ataupun 111,2 juta orang pada usia 65- 79 tahun. Luka kaki diabetik disebabkan oleh gangguan pembuluh darah perifer juga oleh bendungan aliran darah vena yang stasis sehingga menurunkan sirkulasi pada ektremitas bawah kemudian dapat meningkatkan terjadinya edema, LKD juga disebabkan oleh penurunan aliran darah kapiler dan penurunan aliran darah arteri (Jannaim, 2018).

Akibat terjalin pada raga yang mencuat berbentuk kelainan wujud kaki, perih, serta peradangan kaki, apalagi bisa berpotensi amputasi, sebaliknya kasus psikologis yang timbul bisa berbentuk kecemasan, ini bisa timbul diakibatkan oleh pengobatan luka yang dialami oleh penderita selama bertahun-tahun. (Diabetikum 2020).

Prevalensi penderita diabetes di Indonesia pada tahun 2013 usia $\geq 15$ tahun mencapai $1,5 \%$ sedikit lebih rendah dibandingkan prevalensi pada tahun 2018 usia $\geq 15$ tahun, yaitu sebesar 2,0\%. Selain itu, penderita diabetes melitus lebih banyak berjenis kelamin perempuan $(1,8 \%)$ daripada laki-laki $(1,2 \%)$ di Indonesia (Riset Kesehatan Dasar (Riskesdas, 2018).

Data Riskesdas (2013) memperlihatkan Provinsi Sumatera Utara mempunyai prevalensi diabetes melitus dengan komplikasi sebesar $1.8 \%$ juga proporsi penderita diabetes melitus dengan komplikasi sebesar $2.3 \%$. Selanjutnya, prevalensi diabetes melitus di Provinsi Sumatera Utara berdasarkan wawancara yang terdiagnosis dokter dan gejala adalah sebesar $2.3 \%$, dimana jumlah tersebut meningkat dibandingkan dengan survey tahun 2007 yaitu sebesar $1.21 \%$, sedangkan jumlah penderita diabetes melitus di Kota Medan yang didiagnosis dokter dan gejala adalah sebesar 2,7\%.(Fatimah and Siregar 2020).

Rudy dalam bukunya yang bertajuk novel pegangan diabet berkata kalau cedera pada kaki pengidap diakibatkan paling utama oleh neuropati( motorik, sensorik, serta otonom) serta iskemik, dan diperumit oleh peradangan. Hilangnya sensai perih bisa mengganggu kaki secara langsung, semacam mengenakan sepatu yang tidak cocok dimensi serta lain- lain. Penebalan kulit( kalus) hendak pada titik ini serta hendak terjalin hemoragi ataupun nekrosis, yang umumnya diiringi kalus, bisa rusak yang setelah itu membentuk cedera. Cedera yang sangat kerap terjalin merupakan pada kaki disebabkan pembluh darah pada kaki merupakan pembuluh darah yang sangat terjauh dari jantung serta banyak pembuluh darah yang kecil terletak di kaki, setelah itu kaki ialah organ yang sangat rentang terjalin cedera disebabkan kaki sangat gampang bergesekan dengan benda- benda yang terdapat disekitar kita serta pula kaki ialah tumpuan dari beban badan (Saragih, 2020).

Kecemasan ialah sesuatu perasaan yang sifatnya universal, dimana seorang yang hadapi takut, merasa ketakutan ataupun kehabisan keyakinan diri serta merasa lemah sehingga tidak sanggup buat 
berlagak serta berperan secara rasional. Penyakit kronis semacam cedera diabetik bisa memunculkan permasalahan psikologis pada penderita pula keluarga.

Data yang tidak pas bisa memunculkan mispersepsi yang mempengaruhi terhadap keadaan psikologis antara lain tingkatan kecemasan apalagi tekanan pikiran. Cedera diabetik pula ialah penyakit genetik yang bisa diturunkan pada generasi selanjutnya, akibat kurang baik serta komplikasi parah semacam amputasi menaikkan kekhawatiran penderita serta keluarga (Setiawan, 2018).

Aromaterapi ialah pengobatan yang memakai minyak essensial ataupun sari minyak murni buat menolong membetulkan ataupun melindungi kesehatan, membangkitkan semangat, menyegarkan dan menenangkan jiwa serta raga. Aromaterapi saat ini menjadi salah satu terapi komplementer yang tersedia dan banyak digunakan. Pengobatan ini dimaksud selaku pemakaian minyak essensial oil murni dari tumbuhan- tumbuhan aromatik buat meringankan permasalahan kesehatan serta tingkatkan kualitas kehidupan( Faridah, 2019).

Aromaterapi merupakan salah satu terapi non-farmakologi yang dapat mengatasi masalah kesehatan salah satunya kecemasan. Aromaterapi adalah terapi yang menggunakan essensial oil atau sari ekstrak minyak murni untuk membantu memperbaiki dan menjaga kesehatan, membangkitkan semangat, gairah, menyegarkan juga menenangkan jiwa, serta merangsang proses penyembuhan (Sawiji, La, and Sukarmini 2020).
Menurut hasil penelitian (Herman 2016) Sebagai alternatif herbal anti diabetes, ekstrak kuli jeruk memiliki efek mengurangi kadar glukosa darah yang potensial untukdimanfaatkan. Efek tersebut dimiliki oleh senyawa flavonoid yang terkandung dalam kulit jeruk. Pada penderita luka diabetik, maka hal tersebut dapat diatasi dengan cara mengonsumsi antiioksidan. kulitt Jeruk merupakan tumbuhan endemikk dikawasan Asiaa Tenggara, termasukk Indonesia hingga dapatt dengan mudah diijumpai. Esktrak kulit jeruk dilaporkan mengandung berbagai jenis senyawa seperti fenolikk dan flavonoid yang dilaporkan memilikii aktivitass antidiabetess seperti gallic acid, naringin, hesperidin, dan naringenin berbagai jenis antioksi dann seperti flavonoiid dan polifenoll terkandung. di dalam jumlah cukupp besar diseluruhh bagian padaa tumbuh-tumbuhann. Antioksidan alami dari kulitt jeruk menjadii fokuss utama padaa- penelitian ini.(Cicilia Setyabudi, 2015).

Bersumber pada hasil survei dini yang dicoba oleh periset di Asri Wound Care Center Medan pada bulan November 2020, dikenal informasi rata- rata penderita yang melaksanakan perawatan dalam satu hari merupakan 5- 10 orang serta senantiasa melaksanakan perawatan secara berkesinambungan hingga cedera penderita sembuh. Diketahui dari hasil pengkajian selama pasien melakukan perawatan luka kaki diabetik, pasien mengatakan mengalami kecemasan terhadap luka kakinya sehingga mereka hanya mengonsumsi obat farmakologi untuk mengurangi rasa kecemasan dan mengurangi asupan makanan yang mengandung glukosa. Pengobatan atau tindakan seperti pemberian aromatherapi ekstrak kulit jeruk belum dilakukan di Asri Wound Care Center Medan sebagai salah satu 
teknik relaksasi bagi pasien tersebut, dan pasien disana belum mengetahui khasiat aroma dari kulit jeruk juga dapat menurunkan kecemasan dan memberikan efek tenang. Berdasarkan penjelasan tersebut peneliti tertarik untuk melakukan penelitian tentang "Pengaruh Aromatherapi Ekstrak Kulit Jeruk Terhadap Penurunan Tingkat Kecemasan Pada asien Luka Kaki Diabetik di Asri Wound Care Center Medan Tahun 2021".

Bersumber pada pemaparan permalasahan tersebut maka peneliti tertarik untuk melaksanakan riset dengan tujuan untuk mengetahui pengaruh Aromatherapi Ekstrak Kulit Jeruk terhadap penurunan tingkatan kecemasan pada penderita cedera kaki diabetik di Asri Wound Care Center Medan Tahun 2021.

\section{METODE}

Riset ini memakai desaind serta tata cara pre- eksperimen sehingga periset memakai( one tim pre- test[ost uji design), dimana kelompok sasaran akan di observasi baik sebelum dan sesudah dilakukannya perencanaan. Penelitian dilaksanakan di Asri Wound Care Centre Medan yang mempunyai jumlah populasi serta sampel yang lumayan dijadikan responden sehingga mempermudah periset melaksanakan penelitian. Adapun alibi periset menjadikan Asri Wound Care Center Medan sebagaii lokasi penelitian yang lumayan dijadikan responden sehingga mempermudah periset melaksanakan penelitian. Penelitian initelah dilaksanakan selama 7 hari pada tanggal 02 s/d 09 April 2021. Populas idalam riset ini merupakan penderita cedera diabetik pada bulan November 2020sebanyak 20orang di Asri Wound Care CenterMedan. Ada pula yang jadi ilustrasi dalam riset ini merupakan penderita yang hadapi cedera diabetikum serta melaksanakan perawatan cedera di Asri Wound Care CenterMedan. Metode pengambilan ilustrasi dalam riset ini merupakan accidental samplingyaitu pengambilan ilustrasi yang dicoba dengan mengambil permasalahan responden secara kebetulan ataupun responden yang didapat saja.

Informasi primer dari riset ini merupakan informasi dari hasil penyusutan tingkatan kecemasan pada penderita cedera diabetik saat sebelum serta setelah pemberian AromatherapiEkstrak Kulit Jeruk, berdasarkan hasil observasi pada respondens. Data sekunder merupakann data yang telah tersedia dari petugas pelayanan kesehatan di Asri Wound Care Center Medan. Pengumpulan data pada penelitian ini menggunakan instrument lembaran kusioner tingkat kecemasan, (Hamilton Rating Scale for Anxiety/ HRS-A).

Penelitian akan dilakukan setelah lulus uji etik dengan nomor 040, setelah itu peneliti mengajukan penelitian ke Asri Wound Care Center Medan untuk mendapatkan izin penelitian. Setelah pihak AsriWound Care Center Medan mengizinkan periset melaksanakan riset hingga periset hendak menarangkan tentang tujuan riset kepada responden. Jika responden sepakat buat jadi ilustrasi riset, hingga periset mengajukan pesan persetujuan responden buat ditandatangani oleh responden. Periset juga menarangkan khasiat tentang aromatherapi ekstrak kulit jeruk selaku salah satu pengobatan komplementer ataupun relaksasi yang dapat merendahkan tingkatan kecemasan ataupun setres yang dirasakan oleh pengidap dalam upaya kurangi kekhawatiran terhadap pengidap tersebut. 
Setelah kuesioner diisi, instrumen dikumpulkan kembali oleh peneliti dan diperiksa kelengkapannya, kemudian lembar kuesioner kembali diisi oleh responden setelah dilakukan pemberian aromatherapi ekstrak kulit jerukuntuk mengetahui tingkat penurunan kecemasan sesudah diberikan aromatherapi ekstrak kulit jeruk.

Cara kerja yang dilakukan selama pemberian aromatherapi ekstrak kulit jerukadalah persiapan pasien luka diabetik. Dalam pelaksaan pemberian aromatherapi pada pasien luka diabetik yaitu: Beri salam terapeutik kepada responden dan infont consent, kemudian atur posisi klien senyaman mungkin, mencuci tangan dan pakai sarung tangan, teteskan 3 tetes aromatherapi ekstrak kulit jerukpada tissue yang disediakan, anjurkan pasien untuk menghirup aromatherapi ekstrak kulit jerukselama 5-10 menit dan setelah terapi selesai rapikan alat dan atur kembali posisi pasien senyaman mungkin serta lakukan dokumentasi. Kemudian pemberian aromatherapi ditunggu selama 30 menit dan lakukan evaluasi pasien setelah diberikan aromatherapi ekstrak kulit jeruk.

Analisa Informasi yang digunakan sudah diolah serta disajikan berikutnya dianalisis secara Analisa univariat betujuan buat menarangkan ataupun mendeskripsikan ciri tiap periset. Wujud analisis univariat bergantung dari jenis informasinya. Analisis informasi univariat pada biasanya cuma menciptakan distribusi frekuensi serta presentase dari masing- masing variabel yang meliputi usia, tipe kelamin, pembelajaran, pekerjaan serta lamanya menempuh perawatan cedera kaki diabetik dan variabel tingkatan penyusutan kecemasan ( Pre- Test serta Post Test). Analisa bivariat yang dicoba terhadap 2 variabel yang diprediksi berhubugan ataupun bekerjasama, bila informasi distribusi wajar serta memakai uji wilcoxon sign rank test dengan tingkatan keyakinan 95\% artinya apabila $\mathrm{p}<0,05$ hingga $\mathrm{Ho}$ ditolak ataupun $\mathrm{Ha}$ diterima.

HASIL

Tabel 1.

Karakteristik responden kecemasan pada pasien luka kaki diabetik.

\begin{tabular}{lcc}
\hline \multicolumn{1}{c}{ Karakterisstik Responden } & f & $\%$ \\
\hline Jenis Kelamin & 8 & 53.3 \\
Laki-laki & 7 & 46.7 \\
Perempuan & & \\
\hline Umur & 1 & 6.7 \\
45-49 tahun & 5 & 33.3 \\
$50-54$ tahun & 9 & 60 \\
\hline $5-59$ tahun & & \\
\hline
\end{tabular}

Tabel 2.

Distribusi responden sebelum pemberian aromatherapi ekstrak kulit jeruk pada pasien luka kaki diabetik $(n=15)$

\begin{tabular}{llc}
\hline \multicolumn{1}{c}{ Kategori } & $\mathrm{f}$ & $\%$ \\
\hline Kecemasan ringan & 3 & 20 \\
Kecemasan sedang & 5 & 33.3 \\
Kecemasan berat & 7 & 46.7 \\
\hline
\end{tabular}


Tabel 3.

Distribusi responden sesudah pemberian aromatherapi ekstrak kulit jeruk pada pasien luka kaki diabetik $(n=15)$

\begin{tabular}{ccc}
\hline Kategori & $\mathrm{f}$ & $\%$ \\
\hline Tidak ada cemas & 5 & 33.3 \\
Kecemasan ringan & 7 & 46.7 \\
Kecemasan sedang & 3 & 20.0 \\
\hline
\end{tabular}

Tabel 4. Pengaruh aromateherapi ekstrak kulit jeruk terhadap penurunan tingkat kecemasan pada pasien luka kaki diabetik.

\begin{tabular}{lccccccc}
\hline $\begin{array}{c}\text { Aromatherapi } \\
\text { Ekstrak Kulit } \\
\text { Jeruk }\end{array}$ & \multicolumn{9}{c}{ Tingkat Kecemasan } & & \multirow{2}{*}{$\begin{array}{c}\text { Std } \\
\text { Deviasi }\end{array}$} & $\begin{array}{c}\text { Ringa } \\
\text { Cemas }\end{array}$ & $\begin{array}{c}\text { Sedan } \\
\mathrm{n}\end{array}$ & $\begin{array}{c}\text { Bera } \\
\mathrm{g}\end{array}$ & $\mathrm{t}$ Mean & & \\
\hline Pre Test (P) & 0 & 3 & 5 & 7 & 39,13 & 9,094 & \multirow{2}{*}{0,001} \\
\hline Post Test (Q) & 5 & 7 & 3 & 0 & 24,4 & 7,567 & \\
\hline
\end{tabular}

Tabel 2 distribusi frekuensi penurunan tingkat kecemasan pasien luka kaki diabetic sebelum pemberian aromatherapy ekstrak kulit jeruk dengan mayoritas responden mengalami kecemasan berat 7 orang $(46.7 \%)$ dan kecemasan sedang 5 orang (33.3\%), minoritas responden kecemasan ringan berjumlah 3 orang (20.0\%).

Tabel 4 berdasarkan uji normalitas Kolmogorov Sminov pada data pre-test memiliki nilai sig $0.283>0.05$ pada data post-test memiliki nilai sig $0.032>0.05$. Uji Wilcoxon Signed Rank Tes memiliki nilai Rank pre test-post test sebesar 39.13-24.40 dengan $p$-value 0.001.

\section{PEMBAHASAN}

Luka kaki diabetik merupakan salah satu komplikasi dari penyakit. Diabetes Millituss. Pengidap cedera kaki diabetik memiliki permasalahan raga berbentuk cedera yang terletak dikaki serta lama sembuh apalagi hingga berbau tidak nikmat, kelainan wujud kaki keterbatasan mobilitas raga serta ketidakmampuan buat melakukan guna baik. Apabila cedera semain parah, hingga bisa pula dicoba prosedur operasi hingga dengan amputasi kaki.
Perihal tersebut hendak menggangu citra badan pengidap dan hendak menimbulkan akibat psikologi berbentuk kendala kecemasan yang menyebabkan kendala kencing, kesemutan serta mati rasa, tubuh lemah serta gampang letih, dan hadapi kesulitasn tidur malam (Maesaroh, S., Mukhlis, H.,\&amp; Widyastuti, F. 2019). Tingkat kecemasan pasien luka kaki diabetik dapat diatasi dengan terapi non farmakologi yaitu pemberian aromatherapi ekstrak kulit jeruk untuk penurunan tingkat kecemasan.

Hasil penelitian mengenai pengaruh aromatherapi ekstrak kulit jeruk terhadap penurunan tingkat kecemasan pada pasien luka kaki diabetik di Asri Wound Care Center Medan terhadap 15 responden. Sebelum melakukan aromtherapi ektrak kulit jeruk mayoritas yang mengalami tingkat kecemasan berat sebanyak 7 orang $(46,7 \%)$, dan saat sesudah melakukan aromatherapy kulit jerukmayoritas yang mengalami kecemasan berat $5(33,3 \%)$.

Ekstrak kulit jeruk memiliki efek mengurangi kadar glukosa darah yang potensial untuk dimanfaatkan. Efek tersebut dimiliki oleh senyawa 
flavanoid yang terkandung dalam kulit jeruk. Kulit jeruk merupakan tumbuhan endemik di kawasan Asia Tenggara, termasuk Indonesia sehingga dapat dengan mudah dijumpai. Estrak kulit jeruk dilaporkan mengandung berbagai macam senyawa fenolik dan flavanoid yang dilaporkan memiliki aktifitas anti diabetes. Aromatherapi yang menggunakan essensial oil atau sari ekstrak minyak murni untuk membantu memperbaiki dan menjaga kesehatan, membangkitkan semangat, gairah menyegarkan juga menenangkan jiwa, serta mersangsang proses penyembuhan. Sama halnya dengan penelitian yang dilakukan Indrayati didapatkan hasil bahwa kelompok eksperimen lebih banyak pasien luka kaki diabetik yaitu sebesar 57,14\%, kelompok control yaitu sebesar 50,00\% . Usia lanjut beresiko terhadap terjadinya ulkus kaki diabetik, karena fungsi tubuh secara fisiologis menurun, hal ini disebabkan karena penurunan sekresi atau resistensi insulin, sehingga kemampuan fungsi tubuh terhadap pengendalian glukosa darah yang tinggi kurang optimal (Indrayati 2018).

Berdasarkan hasil uji Wilcoxon Signed Rank Tes data yang digunakan hasil pengukuran kecemasan sebelum dilakukan aromatherapi ekstrak kulit jeruk pada hari pertama penelitian dan hasil pengukuran kecemasan sesudah dilakukannya aromatherapi ekstrak kulit jeruk pada hari terakhir penelitian dengan nilai Rank pre test-post test sebesar 39.13-24.40 dengan p-value 0.01. Hal ini menunjukkan bahwa adanya peningkatan responden setelah melakukan pemberian aromatherapi ekstrak kulit jeruk selama 7 hari berturut-turut, hasil ini sama dengan penelitian Rahmayati (2018) mengenai pengaruh aromatherapi ekstrak kulit jeruk terhadap tingkat kecemasan pasien luka kaki diabetik. Hasil penelitiannya memperlihatkan perbedaan tingkat kecemasan pada pasien luka diabetik sebelum dan sesudah diberikan aromatherapy ekstrak kulit jeruk dengan nilai p-value 0,000. Dengan data diatas dapat disimpulkan bahwa ada pengaruh setelah dilakukannya aromatherapi ekstrak kulit jeruk terhadap penurunan tingkat kecemasan hal ini ditunjukkan dengan $p$-value, sehingga Ha diterima dan Ho ditolak.

Hasil penelitian yang dilakukan aromatherapi kulit jeruk diberikan 3 kali seminggu sebelum tidur dan selama 2 minggu dengan jarak $5 \mathrm{~cm}$ dari hidung pada pasien luka diabetik setelah diberikan intervensi terdapat perbedaanyang signifikan $\mathrm{P}<0,05$ pada kecemasan (Faridah . 2019)Setelah diberikan intervensi melakukan aromatherapi ekstrak kulit jeruk responden mengalami perubahan tingkat kecemasan. Melakukan aromatherapi ekstrak kulit jeruk sangatlah baik karena aromatherapi ekstrak kulit jeruk bertujuan untuk merelaksasikan dan dapat menurunkan kecemasan pada pasien dan sangat mudah dilakukan oleh responden.

\section{SIMPULAN}

Tingkat kecemasan responden sebelum dilakukan pemberian aromatherapi ekstrak kulit jeruk mayoritas responden berada pada kategori tingkat kecemasan berat. Tingkat kecemasan responden setelah dilakukan pemberian aromatherapi ekstrak kulit jeruk mayoritas reponden berada pada kategori tingkat kecemasan ringan.

\section{DAFTAR PUSTAKA}

Cicilia Setyabudi, Stefani Tanda, Wenny Irawaty Santosa, Felycia Edi Soetaredjo. 2015. "Studi in Vitro Ekstrak Kulit Jeruk Purut untuk 
Aplikasi Terapi Diabetes Melitus." Jurnal Ilmiah Widya Teknik 14(1): 15-19.

Diabetikum, Ulkus. 2020. "Majalah Kesehatan Indonesia Kualitas Hidup Ditinjau Dari Tingkat Kecemasan Pasien Penderita." 1(2): 33-38.

Faridah, Ida et al. 2019. "Pengaruh Aromaterapi Terhadap Kualitas Tidur, Kualitas Hidup, Kelelahan Dan Kecemasan Pada Pasien Diabetes Melitus." Jurnalinterest.Com: 237-59.

Fatimah, Petti Siti, and Putra Apriadi Siregar. 2020. "Pola Konsumsi Buah Dan Sayur Dengan Kejadian Diabetes Mellitus Pada Masyarakat Pesisir.” 2(1).

Herman, Yakub. 2016. "Potensi Antidiabetes Melitus Senyawa Flavonoid Kulit Jeruk: Sebuah Review Mengenai Mekanisme." Convention Center Di Kota Tegal 4(80): 4.

Indrayati, N., Koto, Y., \& Mulyadi, B. (2018). Penyembuhan ulkus diabetik dengan aplikasi antimikrobial wound. Jurnal Ilmiah Ilmu Keperawatan Indonesia, Vol. 8 No., 2-9.

Jannaim, Jannaim, Ridha Dharmajaya, and Asrizal Asrizal. 2018. "Pengaruh Buerger Allen Exercise Terhadap Sirkulasi Ektremitas Bawah Pada Pasien Luka Kaki Diabetik." Jurnal Keperawatan Indonesia 21(2): 101-8.

Maesaroh, S., Mukhlis, H.,\& Widyastuti, F. 2019). Efektifitas Terapi Hand Tappyng Terhadap Kecemasan pada Perempuan yang Sedang menjalani Persalinan. Wellness

And Healthy Magazine, 1(1), 7-14.

Qurniawati, Dewi, Ajeng Fatikasari, Juniatulo Tafonao, and Elis Anggeria. 2020. "Pengaruh

Diabetes Self-Management

Education (DSME) Terhadap

Perawatan Diri Pasien Luka

Diabetes Melitus." Jurnal Ilmu

Keperawatan 8(1): 10-21.

Rahmayati., E., Raihan, H., \& Nurhayati.(2018). Pengaruh Skala nyeri Pasien Post Operasi Operasi Laparatomi. Jurnal Kesehatan Vol 9 No.3: 427-432.

Riskesdas, Kemenkes. 2018. "Hasil Utama Riset Kesehata Dasar (RISKESDAS)." Journal of Physics A: Mathematical and Theoretical 44(8): 1-200.

Saragih, Lenni, Muhammad Faruq Afifuddin, Imam Subekti, and Rossyana Septiasih. 2020. "Pengaruh Rawat Luka Gangrene Terhadap Pencegahan." JUrnal Keperawatan Terapan (e-Journal) 06(01): 27-35.

Sawiji, Repining Tiyas, Elisabeth Oriana Jawa La, and Ni Ketut Sukarmini. 2020. "Pengaruh Variasi CMC-Na Terhadap Sifat Fisik Dan Stabilitas Sediaan Gel Aromaterapi Kulit Buah Jeruk Limau (Citrus Amblycarpa (Hassk.) Ochse)." Lombok Journal of Science 2(2): 15-21.

Setiawan, Hendri et al. 2018. "Hubungan Tingkat Pengetahuan Dengan Kecemasan Penderita Diabetes Mellitus." Urecol: 241-48. 